\title{
PERSAINGAN PASAR BEBAS GLOBAL MASYARAKAT EKONOMI ASEAN DALAM MENGHADAPI BONUS DEMOGRAFI DI INDONESIA
}

\author{
Oleh : Nur Aprilia
}

\begin{abstract}
ABSTRAK
Industri kreativtas dengan ekonomi kreativitas korelasinya sangat nyata, dikarenakan industri yang sumbernya dari pemanfaatan kreativitas manusia didasarkan keterampilan dan bakat individu dari alam berbudaya untuk menciptakan industri kreatitivitas yang berkoleborasi dengan benar terhadap ekonomi kreatif. Oleh karena itu, industri kreativitas ini kontribusinya sangatlah besar untuk pertumbuhan ekonomi satu negara di bandingkan dengan industri manufaktur. Untuk Negara kita Indonesia semenjak terbentuknya Badan Ekonomi Kreatif (BEKRAF) ternyata pemerintah mulai melirik bahwa industri kreatif disatukan dengan ekonomi kreatif merupakan potensi yang luar biasa terhadap pertumbuhan ekonomi Negara Indonesia di masa mendatang. terkait (1) berkorelasi dengan perluasan lapangan kerja untuk mengatasi.
\end{abstract}

pengangguran mengakibatkan bonus demografi 2045, hingga tenaga kerja produktif lebih besar dibandingkan tenaga kerja non produktif ( $0-15$ tahun +65 tahun ke atas). Belum lagi dihadapi persaingan tenaga kerja (outshorsing) antar Negara, baik di level regional dan Internasional, dan (2) pemerataan pembangunan ekonomi untuk masyarakat sekaligus untuk mengatasi berbagai kesenjangan dalam kehidupan masyarakat. Dalam artikel ini, seperti di uraikan di atas, fokus yang dibahas tulisan artikel ini adalah (1) bangkitnnya ekonomi kerakyatan berbasis industri kreatif dan ekonomi kreatif pada UKM di Bali, (2) peluang dan tantangan dalam menghadapi pasar bebas global Masyarakat Ekonomi Asia dengan 
mengangkat sebuah kasus Perajin tangan di Bali yang mengacu pada analisis dengan pendekatan etnosains dan globalisasi.

\section{PENDAHULUAN}

Badan Ekonomi Kreatif (BEKRAF) pada tahun 2017 lalu sebagai suatu lembaga non departemental yang digagaskan oleh pemerintah guna memperdayakan usaha ekonomi yang berbasis kerakyatan dan inovatif. Pemerintah sedang berusaha membangun sebuah dalam konteks pertumbuhan ekonomi pada sektor real untuk ditingkatkannya penghasialan masyarakat sekaligus memperbaiki kualitas dan kehidupan masyarakat. Selain dari itu, dibangunan ekonomi nasional bukan hanya terfokus pada skala ekonomi makro juga memperhatikan perkembangan skala ekonomi mikro. Kemudian yang digolongkan ke dalam sektor ekonomi mikro itu adalah usaha kecil, dan menengah (UMKM), di mana unit-unit usaha yang dikelola oleh rakyat secara swadaya dan mandiri. Oleh kareana itu, pemerdayaan UMKM sebagai basis ekonomi rakyat yang berlandaskan pada dikembangkanya industri kreatif integraskan dengan ekonomi kreatif. Dan Rupanya pemerintah mulai melirik bahwa hal ini merupakan potensi yang luar biasa untuk pertumbuhan ekonomi bangsa Indonesia di masa mendatang. Begitu pula UMKM ini jumblahnya banyak dan hampir tersebar di seluruh penjuru nusantara, baik dalam aktivitas pengembangan usahanya dilakukan di sebuah desa maupun di perkotaan. Mengingat karakteristik prilaku UMKM ini sebagian besar masih berkategori sektor informal, maka sentra produksi pada rumah tangga (home industry) Kontribusinya sangat signifikan dalam menghadapi badai akibat gejolak ekonomi yang disebabkan oleh kondisi stabilitas ekonomi dalam negeri ini maupun situasi perekonomian global yang dihadapi oleh 
Negara-negara Luar, baik Negara maju Maupun Negara berkembang. Oleh karena itu, industri kreatif dengan ekonomi kreatif sebab akibatnya sangat jelas, karena industri ini bersumber dari pemanfaatan kreativitas masyarakat berdasarkan ketrampilan dan bakat/talenta individu dari alam sana. Perpaduan antara ketrampilan dan bakat/talenta dipoles lewat pembinaan dengan baik, seperti pendidikan formal, pendidikan non-formal (kursus-kursus pelatihan ketrampilan), dan pendidikan informal. Inilah bibit potensi sumber daya manusia yang unggul, mandiri, dan berbudaya untuk menciptakan industri kreatif yang berkolerasi penting terhadap ekonomi kreatif. Oleh karena itu, industri kreatif ini kontribusinya lumayan besar terhadap pertumbuhan ekonomi negara berbanding dengan industri manufaktur.

industri kreatif maupun ekonomi kreatif dalam skala nasional baru dikerjakan oleh pemerintah secara lebih serius. Sesungguhnya, keberadaan unit-unit UMKM ini sebagai penggerak perekonomian kerakyatan sudah dilakukan dari dulu (Geertz, 1987). Seiring berjalannya waktu dan kehidupan masyarakat pada subsektor ekonomi secara kesinambungan mengalami perubahan sesuai dengan kemajuan teknologi. Akibat dari teknologi ini, kemudian dimplikasi terhadap pola kehidupan pasar tradisional bergeser pada pola kehidupan pasar modern. Terlebih di era globalisasi ini dengan dukungan informasi teknologi yang serba canggih maka semua keinginan terhadap berbagai kebutuhan hidup dapat dijangkau dengan gampang, jika finansial yang dimiliki cukup mendukung dan juga memadai. Apa yang terjadi semakin termarginalisasi pasar-pasar tradisional oleh kekuatan ekonomi modern karena dapat ruang dari kapitalisme neoliberalisme dengan berkedok pasar tunggal global. Hal ini dikatikan dengan kualitas hasil produksi dan kualitas jasa pelayanannya maka ditentukan standarnya harus sama di seluruh negara. Sebagai contohnya: MCD, KFC, Minuman teh dan lain-lainnya, maka produk 
barang ini sudah masuk dalam pasar bebas global. Artinya di Negara manapun di dunia, kalau membeli barang tersebut konsumen merasakan hal yang sama. terkait (1) berkolerelasi dengan perluasan lapangan kerja untuk mengatasi pengangguran akibat bonus demografi 2045, sehingga tenaga kerja produktif lebih besar dibandingkan tenaga kerja non produktif $(0-15$ tahun + 65 tahun ke atas). Belum lagi menghadapi persaingan tenaga kerja (outshorsing) antar Negara, baik di level regional dan Internasional, dan (2) pemerataan pembangunan ekonomi bagi masyarakat sekaligus untuk mengatasi berbagai kesenjangan sosia ekonomi dalam kehidupan bermasyarakat. Dalam artikel ini dengan topik “ Persaingan Pasar Bebas Global Masyarakat Ekonomi Asia dalam Menghadapi Bonus Demografi di Indonesia". Selanjutnya, fokus yang dibahas dalam tulisan artikel ini berkaitan dengan masalah di antara sebagai berikut: (1) kebangkitan ekonomi kerakyatan berbasis industri kreatif dan ekonomi kreatif pada UMKM di Bali, (2) peluang dan tantangan dalam menghadapi pasar bebas global Masyarakat Ekonomi Asia, dengan mengangkat sebuah kasus Perajin tangan di Bali.

global MEA serta masalah bonus demografi di masa mendatang Teori globalisai digunakan untuk menganalisis pasarisasi sebagai agenda untuk kapitalilisme neoliberalisme dunia perdagangan yang dikendalikan oleh Negara maju untuk memasarkan hasil produk kerajinanya. hal ini, dipandang dari segi waktu dan ruang dunia kelihatan tanpa sekat yang begitu ketat .berhubungnya mobilitas manusia antar negara, kabupaten, provinsi, kecamatan dan desa sangat mudah dapat dilakukan. Mengingat faktor penemuan di bidang teknologi yang berhubungan dengan mode alat transporatasi dan alat komunikasi yang super canggih untuk mengatasi hambatan gerakan manusia dalam ruang dan waktu tersebut. Akibat pengaruh tersebut, tidak hanya menggeser, namun juga menggantikan pasar tradisional yang kondisinya 
sudah mapan karena tuntutan kemajuan zaman maka diganti dengan pasar modern, seperti supermarket, hypermarket dan swalayan .

\section{HASIL DAN PEMBAHASAN}

1.Kebangkitan ekonomi UMKM di Bali

Desa-desa yang terletak pada didaerah perbatasan dengan Negara-negara tetangga, seperti Malaysia,Brunai Darusalam,Philipina, singapura dan Papua New Gini, maka untuk akses perekonomian masyarakat lebih dekat pada Negara tersebut, dibandingkan ke NKRI. Faktor penyebab utama karena belum diadakan struktur yang melengkapi dan bisa menghubungkan penduduk yang tinggal pada daerah-daerah perbatasan tersebut ke dalam satuan wilayah indonesia. Jadi posisinya masih tetap terisolasi, sehingga mobilitas masyarakat sangat terhambat oleh kondisi sarana transportasi yang tidak memadai untuk melalkukan aktivitas tersebut. Pembangunan ekonomi yang diawali dari daerah terluar atau pinggiran dengan membangunan infra struktur jalan merupakan salah satu strategis pemerintah untuk membuka akses bagi penduduk yang bermukim daerah pedalaman untuk melancarkan roda perekonomian masyarakat di wiliyah tersebut. Kalau ini sudah berhasil diwujudkan maka persoalan-persoalan yang berkaitan dengan kesenjangan ekonomi antar wilayah di Indonesia dapat diatasi.Pada akhirnya, tujuan pembangunan ekonomi itu bagi masyarakat merata di seluruh tanah air. Hal ini, juga berimplikasi terhadap perluasan kesempatan kerja bagi penduduk usia produktif, sekaligus pula mengatasi masalah penduduk yang miskin,karena beban ekonomi keluarga yang disebabkan oleh pendapatan dalam rumah tangga tidak cukup untuk memenuhi kebutuhan hidup sehari-hari. 
Salah satu langkah strategis untuk Mengerjakan aspek industri kreatif yang berkolaborasi dengan aspek ekonomi . Walaupun aslinya kedua konsep ini selalu terkait satu sama lain,Oleh Sebab itu, baik industri kreatif dan ekonomi kreatif saling melengkapi satu sama lainnya dan berjalan beriringan secara bersama. Secara konsepsional Departemen Perdagangan (2009) menjelaskan bahwa industri kreatif yaitu industri yang berasal dari pemanfaatan keterampilan, kreativitas, dan bakat individu dalam menciptakan kesejahteraan dan membuka lapangan pekerjaan bagi penduduk.Industri ini lebih terfokus untuk memberdayakan daya cipta dan daya kreasi bagi setiap individu.Oleh sebab itu, industri kreatif ini yang bersumber pada kreativitas, keterampilan dan bakat (talenta) yang melekat dari individu yang secara potensial mampu untuk menciptakan kekayaan dan lapangan pekerjaan melalui eksploitasi serta pembangkitan daya cipta dan kekayaan intelektual dari individu bersangkutan. Adapun ciri-ciri keunggulan daripada industri kreatif antara lain sebagai berikut: (1) menghasilkan berbagai desain kreatif yang melekat pada produk barang atau jasa yang dihasilkan, dan (2) industri ini juga pada umumnya merupakan hasil produk teknologi informasi yang dapat menjadi solusi untuk mengatasi masalah pada kehidupan masyarakat sehari-hari. Jadi industri kreatif kontribusinya sangat signifikan terhadap perkembangan ekonomi suatu Negara, dan bahkan ikut mendorong peningkatan ekonomi secara global.Sebagaimana dipahami bahwa kreativitas manusia ini merupakan potensi sumber daya ekonomi yang dilahirkan dari sektor industri kreativitas dan motivasi dari setiap individu. Di Indonesia sektor industri kreatif yang berdampak terhadap pertumbuhan ekonomi secara garis besarnya meliputi beberapa sektor antara lain sebagai berikut: (1) kerajinan (2) periklanan (3) pasar barang seni (4) Arsitektur (5) design (6) fashion (7) film, vidio, dan fotografi (8) seni pertunjukkan (9) musik tradisional (10) riset desaign dan (11) kuliner. Ke-11 jenis industri kreatif 
ini masih bersifat manual, dikarenakan belum penerapan teknologi. Namun, berbeda dengan sektor industri kreatif yang berbasis teknologi. Di antara jenis industri kreatif yang berbasis teknologi meliputi sebagai berikut: (1) indusri Layanan komputer, (2) musik, (3) industri Permainan (4) industri pertelevisian. Selanjutnya, ekonomi kreatif yang telah ditetapkan pada tahun 2005 oleh WIPO menjelaskan ini kegiatan ekonomi masyarakat menghabiskan sebagian waktunya untuk menghasilkan ide. Namun, gagasan yang dihasilkan ini tidak hanya melakukan hal-hal yang bersifat rutinitas atau mengulangi, sebab bagi masyarakat menghasilkan ide menjadi keharusan untuk dilakukan demi kemajuan masa ke depannya.

2. tantangan dalam menghadapi pasar bebas global MEA

Perubahan dari faktor agraris berpindah ke faktor non agraris cenderung generasi muda sebagian besar tidak menggeluti pekerjaan sebagai petani. Justru, lebih memilih pekerjaan di faktor jasa dan perdagangan. Kedua sektor ini lebih menghasilkan, karena memberikan penghasilan lebih baik berdasarkan ketentuan gaji minimum regional. Peluang kerja semakin luas bisa diperoleh pada faktor industri pariwisata. Pulau Bali dengan obyek wisata budayanya tersohor di seluruh penjuru dunia. perekonomian di Bali dipengaruhi secara signifikan oleh sebagaian wisatawan tersebut. Kemudian berkaitan dengan peluang dan tantangan industri kreatif dan ekonomi kreatif ini dalam era pasar bebas global MEA serta penyerapan tenaga kerja akibat bonus demografi dipaparkan sesingkat di bawah ini sebagai berikut. (1) peluang industri kreatif dan ekonomi ini dalam era pasar bebas global MEA. Bali sebagaian destinasi kunjungan wisata dunia luar, maka pelancong luar negeri, yang datang ke Bali berasal dari seluruh belahan 
dunia. Kunjungan turis setiap pertahunnya selalu mengalami peningkatan. Sebab itu, dilakukannya kunjungan ke objek-objek tempat wisata, baik sifatnya natural maupun atraksi Seni. Turis yang datang ke daerah ini, memang bersungguh-sungguh untuk liburan. Tetapi, ada juga turis dari luar negeri itu berlibur sambil menjalankan bisnis. Produk barang kerajinan yang paling diminati terutama Di kerajinan. Produk kerajinan ini dikerjakan secara baik oleh perajin profesional, sehingga hasilnya sebagai sebuah karya seni beraura kharismatik, dan konsumen sebagai penikmat seni merasakan sebuah karya seni yang agung. Peluang ini digunakan oleh perajin dan pengusaha yang bergerak di sektor industri pariwisata, seperti gallery, artshop, showroom patung kayu, pemandu wisata. Oleh karenatu, kerajinan tangan pengrajin Bali mampu menembus pasar global, sehingga ekonomi kreatif orang Bali dijadikan role model untuk menghasilkan uang, tahan banting, dan selalu inovatif. Peluang lainnya dapat diwujudkan dengan industri kreativitas dengan memasarkan produk-produk barang kerajinan melalui jaringan online. Transaksi dan pemasaran produk kerajinan itu bisa dilakukan secara online dengan membuka situs website belanja online. Hal ini, akan lebih mudah dijualbelikan,sehingga dapat menekan biaya dan waktu lebih cepat.

tantangan industri kreativitas dan ekonomi kreativitas ini dalam era pasar bebas global MEA. Hambatan mendasar dalam dikembangkanya industri kreatif dan ekonomi kreatif ini untuk memasuki pasar bebas global MEA. Ada beberapa hal perlu diperhatikan bagi pemgguna bisnis yang bergerak pada sektor usaha perdagangan. (1) ini memasarkan produk barang karya kerajinan, tidak cukup mengandalkan dari satu pihak ke pihak lain. Perlu menciptakan ruang baru mengingat kemajuan informasi dan teknologi yang semakin canggih. Oleh sebab itu konsumen bisa dengan gampang mengakses barang itu melalui mode pemasaran online. Model cara 
pemasaran online ini, pembeli luar negeri dapat mengetahui produk barang itu, baik kualiatas, model, dan harganya sesuai selera. (2) bentuk promosi produk kerajinan ini, hendaknya juga memperkenalkan semua produk kerajinan yang dibuat oleh penduduk Bali, baik bahan bakunya,variasi dan jenis modelnya, (3) (SDM) dan teknologi, untuk mengatasi persoalan ini, jaringan kerjasama antara dunia usaha,akademis, pemerintah,komunitas perajin, disinergikan untuk menghasilkan produk yang baik dan berkualitas serta bervariasi.

\section{KESIMPULAN}

Berdasarkan pembahasan dapat disimpulkan sebagai berikut.

1. Industri kreativitas dan ekonomi kreativitas dalam praktiknya harus berkolaborasi, karena ke dua bentuk perilaku akvitas ini ber sinergi satu sama lainnya dan selalu berjalan pada waktu sama. Hal ini, merupakan terakses modal dari sumber daya manusia di masa mendatang merupakan basis pembangunan Nasional.

2. Bangkitnya industri kreativitas dan ekonomi kreativitas dilalui pembentukan Badan Ekonomi Kreativitas merupakan upaya untuk memperdayakan ekonomi kerakyatan, karena basis UMKM, mengingat kontribusinya sangat signifikan untuk menjaga stabilitas ekonomi nasional.

3. Peluang dan tantangan industri kreatif dan ekonomi kreatif dalam era pasar bebas global MEA serta penyerapan tenaga kerja akibat bonus demografi Peluang terbuka luas mempasarkan produk-produk barang kerajinan bisa dipasarkan langsung kepada Turis yang berkunjung ke Bali. 


\section{DAFTAR PUSTAKA}

Comarff, J dan Comarff, J.L. 2001. "Millennial Capitalism: First Thoughts on a Second coming" dalam Capitalisme and the Culture of Neoleberalism. Durham \& London: Duke University Press.

Darmana, K. 2004. Kajian tentang Bentuk dan Makna Simbolik Seni Prasi dalam Kehidupan Kultural Masyarakat Bali, Tesis. Yogyakarta: Program Pascasarjana Universitas Gajah Mada.

Eriksen, H. (Ed). 2003. Globalization Studies in Anthropology. London-Sterling, Virginia: Pluto Press.

Sucipta, I N. 2017. Model Pengembangan Industri Kreatif. Bali Post Nomor 265 Tahun Ke-69 Hal. 6 Kolom 2-5. Denpasar: PT Bali Post.

Tsing, A.L. 2005. Friction An Ethnography of Global Connection: Princeton \& Oxford.

Princeton University Press.Geertz. C. “Keyakinan Religius dan Perilaku Ekonomi di Sebuah Desa di Jawa Tengah: Beberapa Pemikiran Awal", Kebudayaan Dan Pembangunan Sebuah Pendekatan Terhadap Antropologi Terapan di Indonesia (Penyunting: Colletta,

Nat.J. dan Umar Kayam). Jakarta: Yayasan Obor Indonesia.Lewellen, T.C. 2002. The Anthropology of Globalization: Cultural Anthropology Enters The 21 St. Century. London: Bergin \& Garvey.

Ahimsa-Putra, HS. 1985. "Etnosains dan Etnometodologi Sebuah Perbandingan" dalam Masyarakat Indonesia Majalah IImu-IImu Sosial Indonesia, Nomor 2, Tahun Ke II, Hal 103-133. Jakarta: Lembaga IImu Pengetahuan Indonesia. 